\title{
APPLICATION OF GEOPHYSICAL METHODS FOR MONITORING OF SURFACE AND SUBSURFACE CHANGES OF ORIGIN ARCHAEOLOGICAL TERRAINS - CASE STUDIES OF SITES IN THE CZECH REPUBLIC
}

\author{
R. Křivánek \\ Institute of Archaeology of the Academy of Sciences of the Czech Republic, Prague, v.v.i., Department of Archaeology of \\ Landscape and Archaeobiology, Letenská 4, 11801 Prague 1, Czech Republic - krivanek@ arup.cas.cz
}

Session D, D-4

KEY WORDS: Geophysical method, Non-destructive Archaeology, Magnetometric measurement, Hillfort, Enclosed area, Czech Republic

\begin{abstract}
:
Geophysical methods could be used in wider scale for monitoring of changes of different archaeological terrains and types of archaeological situations. Agriculture, afforestation or other changes of land use play important role in real preservation of surface and subsurface and subsoil archaeological layers. Quality of many prehistoric, early medieval or medieval archaeological sites is rapidly changing during the time. Many of archaeological situations are today preserved only as subsurface remains of archaeological situations and various anthropogenic activities. A substantial part of these activities and their state of preservation can still be also traced by geophysical methods. Four examples from various types of archaeological sites in this paper document different possibilities of applied geophysical methods always dependent on state of archaeological site and conditions of measurements.
\end{abstract}

\section{INTRODUCTION}

\subsection{General Instroduction}

Geophysical methods belong a longer time between standard methods of non-destructive archaeology. In comparison with the methods of remote sensing and aerial archaeology geophysical methods can't in short time to collect data about large territory, but their advantage is primarily in the special accuracy and sensitivity of surface measurement. Identification and monitoring of sites or partial archaeological situations has always been the primary objective of geophysical method in archaeology, especially in the context of ongoing or planned archaeological investigations. But due to changes in the speed and quality of data collection or processing we can also use these geophysical measurements for spatial monitoring of changes in different way endangered archaeological sites and landscapes. In the article the results of selected examples represent only a small portion of long-term experience with application of geophysical methods on different types of archaeological sites and in various field conditions of measurement.

\subsection{Topic in projects}

The topic of geophysical monitoring of changes of archaeological terrains and situations of sites has been addressed in more archaeological projects (for example Fassbinder, 2009, Löcker, 2009, Erkul et al., 2011, Sirri Seren, 2011, Lick, 2011, De Smedt et al., 2013, Gaffney et al., 2013). In case of the Czech Republic this topic was as a part of several projects concentrated to various enclosed or fortified sites, cooperation of non-destructive archaeological methods or comparison of results from more the same types of site. Possibilities of different geophysical methods were for example tested in project „The Identification of Destroyed Fortifications and Internal Structure of Settlement of Hillforts" PK99P04OPP007 - Monument care department of the Ministry of Culture of the Czech Republic, Krrivánek 1999-2001 (Křivánek, 2000, 2001). Many of newly identified sites from aerial prospection were surveyed during project "Prehistoric Settlement Pattern in Bohemia - The potential of nondestructive archaeology" - 404/97/K024 - Grant Agency of the Czech Republic, Gojda et al. 1997-2002 (Křivánek, 2003, 2006, Gojda et al., 2004, Kuna et al., 2004). Terrains of Celtic oppida were systematically monitored during project "Geophysical survey in archaeologically uninvestigated parts of Czech oppida" - A8002301 - the Grant Agency of the Academy of the Sciences of the Czech Republic, Křivánek et al. 2003-2007 (Křivánek, 2005, 2008, Křivánek, Danielisová, Drda, 2013). Non-destructive methods were compared in project „Inner bailey of Libice stronghold - possibilities of non-destructive archaeology and modern technology in the process of study of archaeological sources" - KJB800020803, Mařík et al. 20082010 (Křivánek, Mařík 2009, Mařík, Křivánek, 2012). The other early medieval hillforts have been studied in Czech-Polish project "Stratigraphy of the selected strongholds of the oldest State of Přemislides and Piasts in the light of the comparative non-invasive investigation" IAE PAN, Oddzial Poznan + Institute of Archaeology AS CR Prague, v.v.i., Kara - Křivánek from 2010 (Křivánek, 2013b, Křivánek, Tabaka, 2011). Monitoring of various enclosed areas was also a part of the internal archaeogeophysical project of the Institute of Archaeology in Prague focused "Enclosed areas in prehistory and the Early Medieval period" - research project AV0Z80020508 Křivánek et al. 2008-2013 (Křivánek, 2010, 2011, 2014, 2015).

\subsection{Applied methods}

In four chosen examples of application of geophysical measurement there were used results of three different 
geophysical methods. Magnetometry was the most powerful geophysical method whose surface results were combined with the result of the other two geophysical methods, resitivity measurements and radar. For magnetometric surveys of large areas of arable fields or meadows two different types of magnetometers were used. Gradient variant of the caesium vapour magnetometer Smartmag SM-4g (Scintrex, Canada) was carried out with one profile measurements with the density of data approx. 1x0.25 m (Zlončice). Five channel magnetometer system Magneto-Arch with fluxgate gradiometers FMG-650B (Sensys) and parallel five profile measurements was carried out with the density of data $0.5 \times 0.2 \mathrm{~m}$ (Prague-Vinoř, Třebsko, Červený Dvůr,). Magnetometer measurements (in common grid net $50 \times 50 \mathrm{~m}$ ) were focused primarily to identification of various sunken features or burned situations. Geoelectric resistivity surveys of particular perspective areas were carried out with the instrument RM-15 (Geoscan Research, U. K.) with Wenner configuration of electrodes A0.5M0.5N0.5B (or A1M1N1B) and density of data $1 \times 1 \mathrm{~m}$ (Prague-Vinoř, Červený Dvůr,). Resistivity measurements were focused on monitoring of the shallow subsurface remains of stony situations and their destructions. For profile radar measurement was used GPR Cobra-wifi II (Radarteam, Sweden) with possibility of parallel observation of two different depths of features (Prague-Vinoř). GPR measurements were focused primarily on verifying deeper archaeological situations and the state of conservation of the site. Orientation of profiles was chosen according to previous results of the other geophysical methods.

\subsection{Processing of data}

Data from caesium vapour magnetometer were transferred and processed by software Oasis-montaj (Geosoft, USA). Data from five channel fluxgate magnetometer system were processed and preliminary processed by software Magneto (Sensys, Germany) and later processed by software Surfer (Golden software, USA). Data from geoelectric resistivity measurement were processed in software Surfer (Golden software, USA). Data from GPR measurements were processed in software Prism (Radar Systems, Latvia). Later combinations of geophysical data with plans or aerial photographs were finally processed in software Photoshop.

\section{EXAMPLES OF RESULTS}

Four thematic examples of application of geophysical methods for monitoring of changes of various archaeological terrains were chosen for this paper. Hillfort Prague-Vinor is a part of the natural reserve with sandstone bedrock. Quadrangular enclosure near Třebsko lies on long-time ploughed plots with typical soil erosion on sloped terrain. Remains of the castle garden architecture in Červený Dvi̊r are situated in long-maintained park with repeated forestation. Fortified site near Zlončice is situated on dominant promontory and sand-gravel terrace with agricultural land use above the Vltava River. But each theme could be also demonstrated by examples from other similar sites. Different themes we could find also in case of monitoring various Czech prehistoric or early medieval settlements, burial cemeteries or production areas.

\subsection{Monitoring of deeply ploughed areas of hillforts with repeatedly remodelled terrain}

New systematic geophysical survey of early medieval (Slavic, $11^{\text {th }}-12^{\text {th }}$ century AD) hillfort in Prague-Vinoř, district Prague 9, could be representative example of efficient combination of geophysical methods in monitoring of state of subsurface archaeological situations inside of protected archaeological monument (Figure 1). The results of extensive magnetometric measurements of complete ploughed area of inner acropolis and outer bailey confirmed presence of many subsurface remains of various sunken features, but also very variable state of these situations in different areas of hillfort. The results of subsequent particular geoelectric resistivity measurement then helped to separate ploughed out remains of subrectangular stony structure of later medieval stronghold $\left(14^{\text {th }}-15^{\text {th }}\right.$ century AD) inside of hillfort. Additional profile measurements by GPR then verified poor state of subsoil preservation of stony remains of extinct stronghold. In the future there will be planned combination of geophysical data with results of metal detector surveys and field artefact collection.

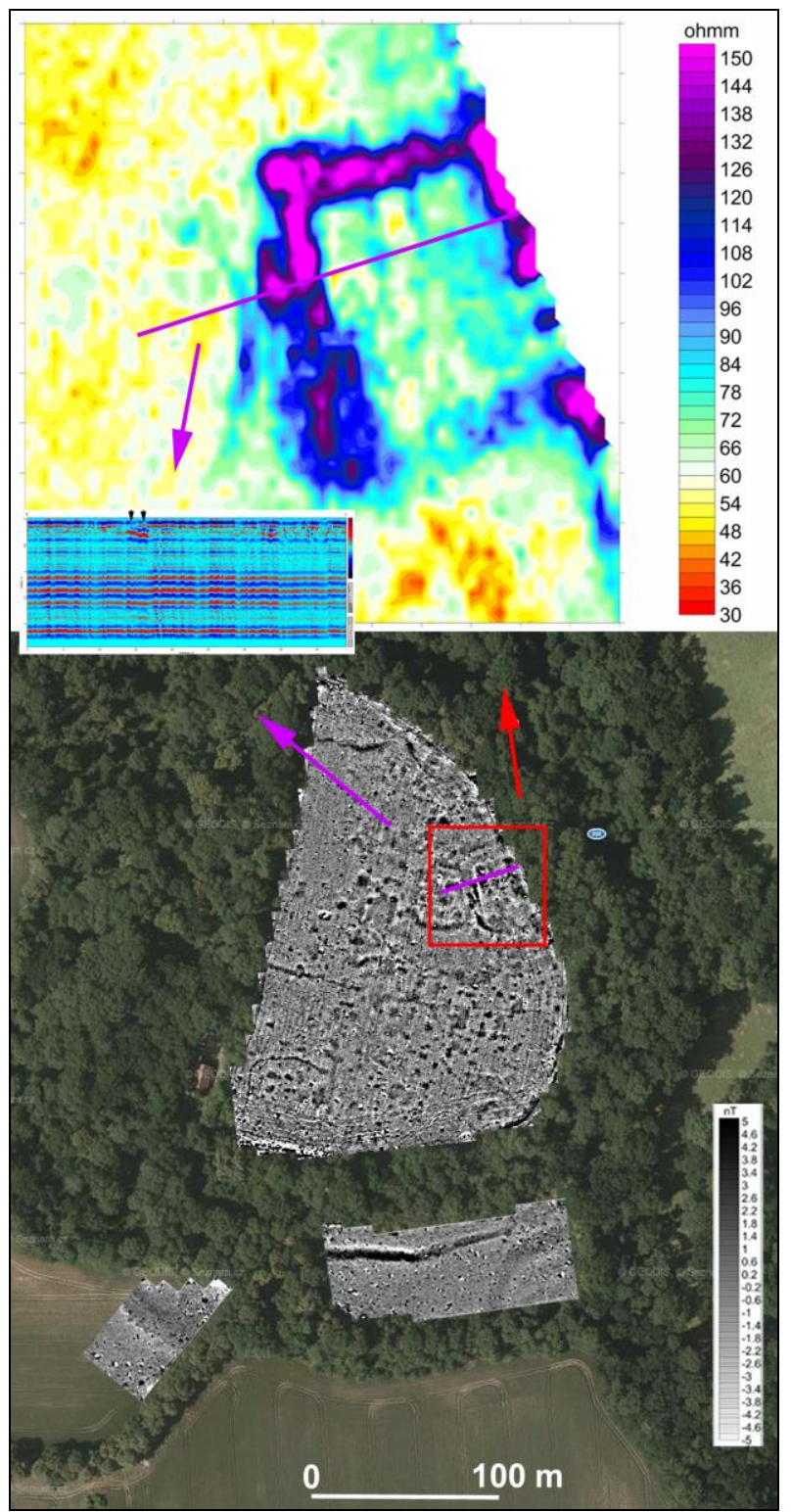

Figure 1. Prague-Vinoř, district Prague 9. Combination of aerial photograph of the site from 2010 and results of magnetometric, geoelectric resistivity survey and GPR measurement inside of hillfort (source of aerial photo: www.kontaminace.cenia.cz; total surveyed area - magnetometry: approx. 3.6 ha; detail of geoelectric resistivity measurement: approx. 0.3 ha; geophysical survey: Křivánek 2011-2013). 


\subsection{Monitoring of specific enclosed sites fully extinct in agricultural terrain}

Contribution of geophysical prospection we can document for example on results of surveyed La Tène quadrangular enclosures (in Czech and German archaeology are sites named "Viereckschanzen"). These sites represent a specific type of late Iron Age enclosure often not far from settlement areas. Detailed magnetometric measurement of La Tène quadrangular enclosure Třebsko II, district Př́bram in Central Bohemia contributed to the new exact identification of a deeply ploughed site which was still visible in terrain and aerial photographs from 1950s, but a few decades later was totally ploughed out (Figure 2). Magnetometric results helped identify the perimeter rampart (now is ploughed out on three sides, fourth side was changed to terrace), outer perimeter ditch (not preserved in terrain) and groups of inner sunken features near corners or along the perimeter of origin quadrangular enclosure (Křivánek, 2013a). Geophysical surveys of the same type of enclosure were carried in more bohemian Iron Age sites often with very similar shapes, dimensions or distribution of sunken features inside of enclosures.

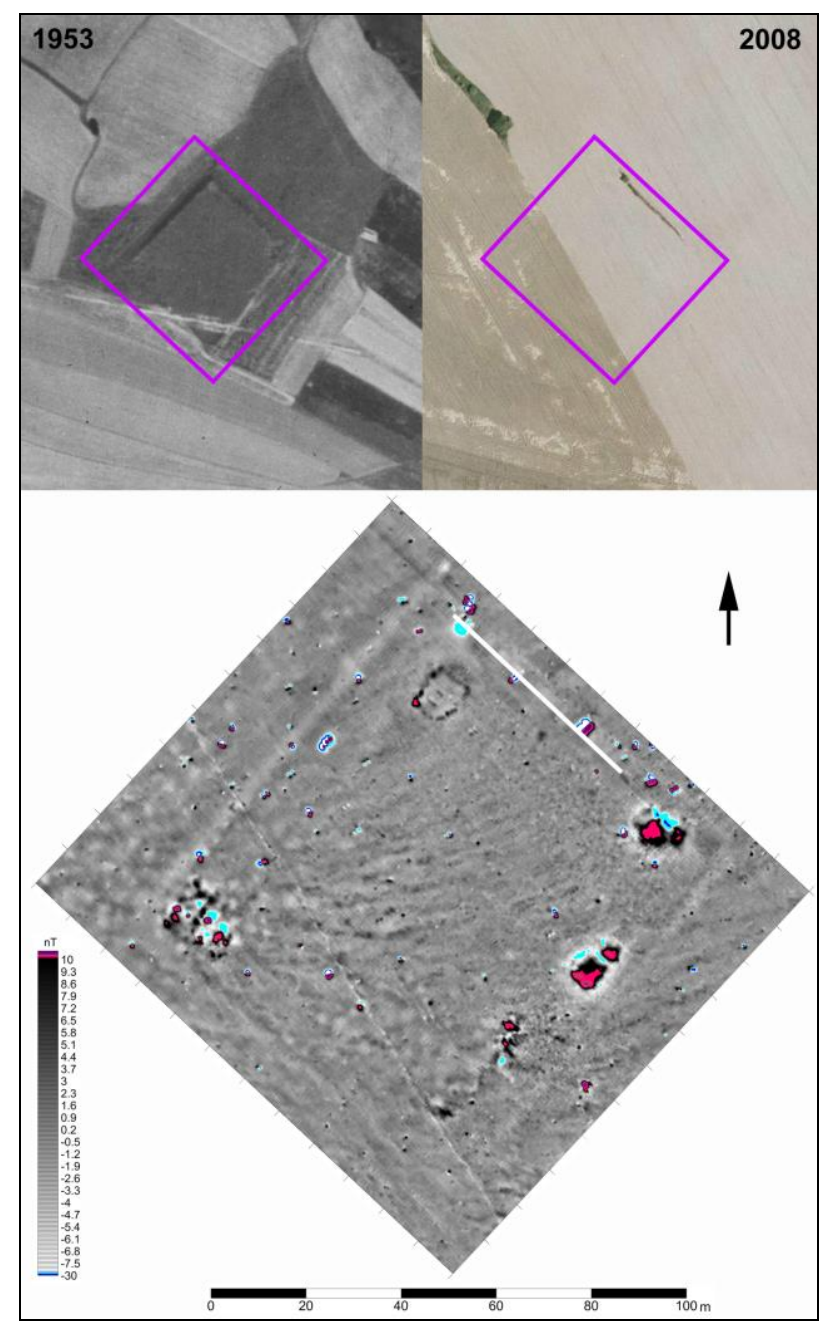

Figure 2. Třebsko, district Př́bram. Comparison of details of aerial photographs of the site from 1953, 2008 and result of magnetometric measurement of ploughed out La Téne quadrangular enclosure (source of aerial photographs: www.kontaminace.cenia.cz; surveyed area: approx. 1.2 ha; geophysical survey: Křivánek 2012).

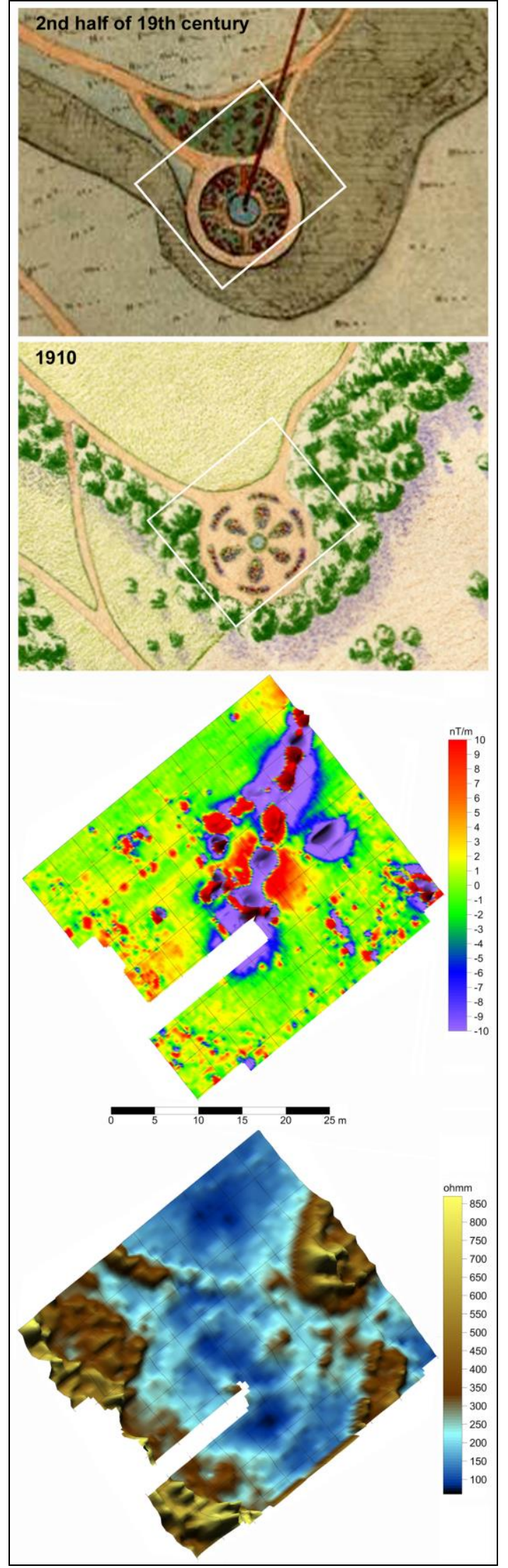

Figure 3. Červený Dvůr, cadaster Chvalšiny, district Český Krumlov. Comparison of old plan details (from 2nd half of 19th century and 1911) and results of magnetometric and geoelectric restivity measurements of area of extinct rose garden (surveyed area: approx. 0.2 ha; geophysical survey: Křivánek 2013). 
The other examples of degradation of ploughed out subsurface layers of ditches were also monitored in the Czech Republic on Neolithic circular enclosures (roundels) or another prehistoric ditch enclosures with various shape, dimension and location in the field..

\subsection{Monitoring of changed afforested terrains of the castle parks}

Monitoring of repeatedly changed and also repeatedly afforested parts of castle parks or gardens represent different specific and new application of geophysical techniques in protected areas of medieval or modern castles. Due to quite complicated work in the field and different aims of heritage geophysical measurements it was important to combine more geophysical methods. Example of efficient particular combination of two different geophysical methods in verification of area of former rose garden (rosarium) is from park of the castle Červený Dvůr, cadaster Chvalšiny, district Český Krumlov in South Bohemia (Figure 3). Result of magnetometric measurement confirmed presence of two types of water supply (one metal pipe line and one wooden pipe line with metal coupling) to extinct rose garden and central fountain. Result of geoelectric resistivity measurement identified subsurface remains of circumferential paths, masonry of corner bastion and origin ornamental flower beds of extinct rose garden (Křivánek, 2014).

Interpretation of geophysical data was possible to do due to possibility of comparison with various details of old plan of the castle park architecture. Geophysical methods were here used in monitoring of ten different castle park and garden areas.

\subsection{Monitoring of newly proven archaeological monuments without heritage protection}

Result of geophysical survey of prehistoric multiply enclosed site near Zlončice, district Mělník document advantage of surface geophysical methods in less suitable conditions for efficient aerial prospection. Large scale magnetometric surveys (out of disturbed areas of water pipe line) clearly confirmed a fortified site, very probably prehistoric hillfort, which was previously discovered only by field artefact collection by regional amateur archaeologist (Figure 4). Several systems of ditches together with proven very intensive sunken settlement features (pits) were identified without any relics of rampart (Krrivánek 2013c). From the results is seems to be quite a lot of subsurface situations (ditch fortifications, its entrances, pits) in relatively good state of subsurface preservation (probably with rare deep ploughing of agricultural terrains). Because this site is still without archaeological verification, but also without adequate protection, the results of non-destructive surveys will be used to define the extent of new immovable prehistoric archaeological monument.

\section{CONCLUSION}

\subsection{Summary and comparison of results}

Results of presented examples in this article illustrate the wide range of possibilities for application of geophysical methods in monitoring of subsurface archaeological terrain in the Czech Republic. The results show that monitoring of plowed sites we can't do without magnetometry results. The application of this non-destructive method in scale of more hectares contribute to the knowledge of extensive prehistoric and early medieval sites of type hillforts, fortified settlements or enclosures with

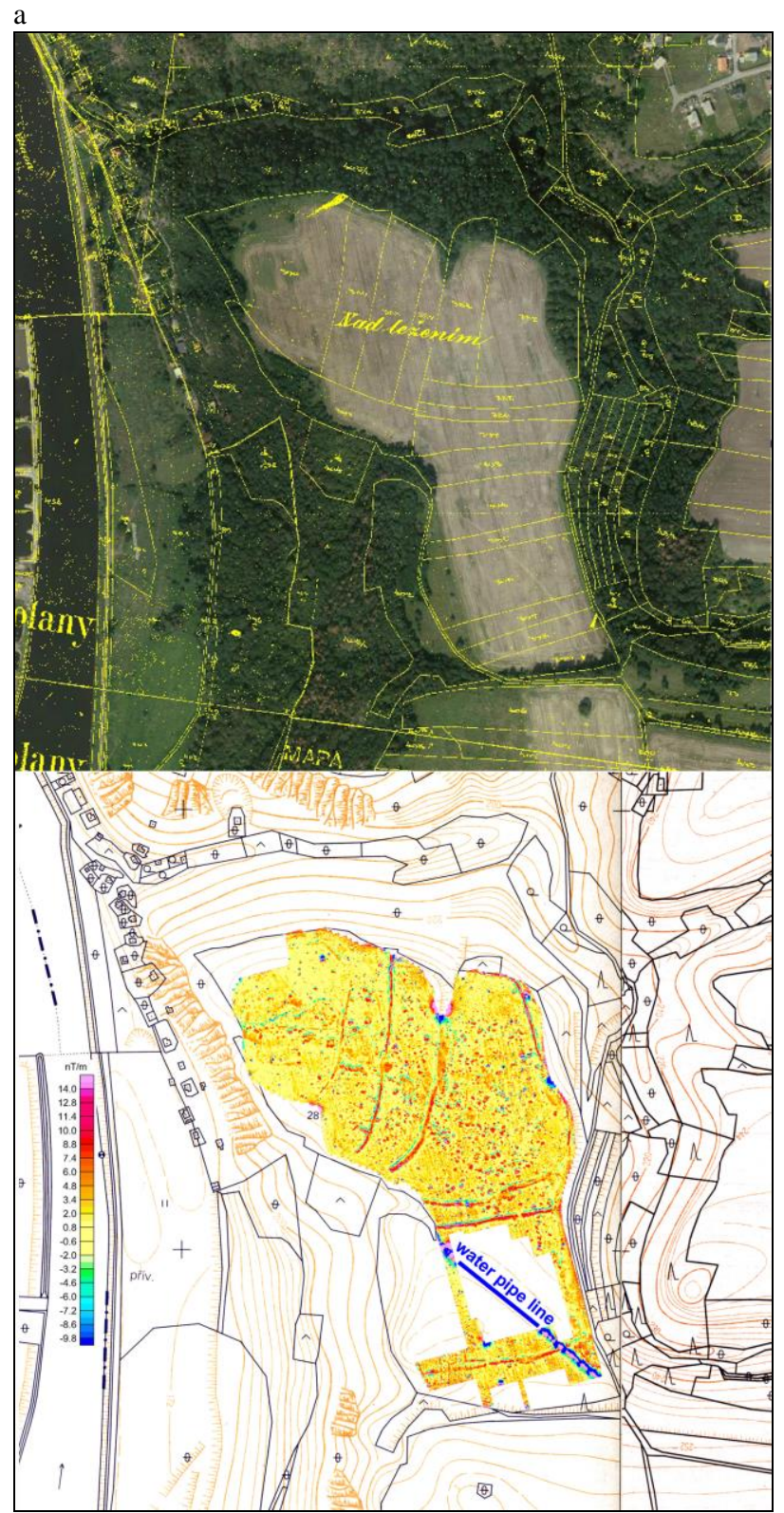

Figure 4. Zlončice, district Mělník. Comparison of aerial photograph of promontory from 2010 in combination with data of the land register (from the middle of 19th century) and result of magnetometric survey (source of aerial photograph: www.kontaminace.cenia.cz; surveyed area: approx. 9.5 ha; geophysical survey: Křivánek 2008-2010).

a predominance of features sunken into the subsoil. With the same method we can also separate burned materials in fortifications or other features and places of some production activity. Level of magnetic anomalies can give as also information about the state of subsoil preservation of features, generally also about changes of preservation and erosion of site (Querrien, 2009, Křivánek e al., 2013). Substantial restrictions on the application of magnetometry, however, is the contamination of area by magnetically interfering materials, the presence of modern metals, range of backfills or other recent disruption of the origin relief of site.

The results from archaeological sites used in medieval and modern period confirm importance of combination of different geophysical methods. Separation of sunken features or burned 
materials from magnetometry here could be added to distinguish the foundations of masonry or other situations with a stone structure by resistivity measurement. Relative laboriousness of field measurements limits the application of the method primarily on monitoring smaller areas up to 1 hectare. The main limitation of resistivity method then is the need of stable climatic and humidity conditions during measurement (without rain and without high levels of ground water).

The application of GPR measurements it will pay in later stage of archaeological prospection of site when we have some results of other geophysical methods. In this time we can more efficiently chose suitable areas for radar measurement. The main advantage of GPR measurement is in possibility of monitoring of deeper archaeological situations, like stony or masonry remains or cavities, in depth of a several meters. Substantial restriction of GPR application is suitable (flat) terrain condition and extent of modern electromagnetic interferences, engineering networks, backfills or other landscape changes.

\subsection{General conclusion}

Geophysical methods we can use for monitoring of subsurface changes of archaeological terrains in different settled, enclosed, fortified, burial, production and other areas. In more complex situations of repeatedly used sites a combination of several suitable geophysical methods increase the efficiency of survey. Possibilities and actual effectiveness of geophysical method but also depends crucially on the field, soil and geological conditions, pedological processes or level of landscape changes of each site. More results could confirm that during the time is changing not only state of subsurface preservation but also possibilities of identification of archaeological situations. Efficiency of interpretation of geophysical measurements could increase also combination of data with results of aerial prospection, LIDAR, field artefact collection, metal detector survey or geochemistry. Complex of these data of nondestructive archaeology could be used as important argument for adequate protection of unique archaeological sites or change of regime of land use of areas of archaeological monuments.

\section{REFERENCES}

De Smedt, P., Saey, T, Van Meirvenne, M, 2013. An electromagnetic induction survey of the Stonehenge landscape. In: Neubauer, W. - Trinks, I. - Salisbury, R. B. - Einwögerer (eds.): Archaeological prospection. Proceedings of the 10th International Conference on Archaeological Prospection, Vienna, May 29th - June 2nd 2013. Austrian Academy of Sciences Press, Wien, pp. 29-30.

Erkul, E., Stümpel, H., Wunderlich, T., 2011. Geophysical investigation of the Hittite city of Sarissa. In: Drahor, M.; Berge, M (eds.): Archaeological prospection, Archaeology and art publications, 2011 Izmir, pp. 40-44.

Fassbinder, J. W., 2009. Global survey of the frontiers of the Roman Empire in Southern Germany, UNESCO World Heritage Site. ArcheoSciences, revue d'archéométrie, suppl. 33 (Mémorie du sol, espace des hommes), Presses de Universitaires de Rennes, pp. 55-58.

Gaffney, V., Gaffney, C., Garwood, P., Neubauer, W., Chapman, H., Löcker, K., Baldwin, E., 2013. Stonehenge Hidden Landscape Project: Geophysical investigation and landscape mapping of the Stonehenge World Herritage Site. In: Neubauer, W. - Trinks, I. - Salisbury, R. B. - Einwögerer (eds.): Archaeological prospection. Proceedings of the 10th International Conference on Archaeological Prospection, Vienna, May 29th - June 2nd 2013. Austrian Academy of Sciences Press, Wien, pp. 19-22.

Gojda, M. et al., 2004. Ancient Landscape, Settlement Dynamics and Non-Destructive Archeology - Czech research project 1997-2002. Prague, Academia.

Křivánek, R., 2000. Způsoby využití geofyzikálních měření jako metody průzkumu hradišt' - The ways of use of geophysical measurements as a method of survey of hillforts. Archeologie ve střednich Čechách 4 - Archaeology in central Bohemia 4, ÚAPPSČ Praha - Institute of archaeological heritage in central Bohemia Prague, pp. 489-503.

Křivánek, R., 2001. Early Medieval hillfort Přistoupim - an example of role of large scale magnetometric prospection to the correct protection of archaeological monument. In: Doneus, M. Eder-Hinterleitner, A.-Neubauer, W. (eds): Archaeological prospection - 4th International Conference on Archaeological Prospection, Vienna 19.-23.9.2001, pp. 135-137.

Křivánek, R., 2003. Contribution of geophysical measurements for survey and protection of hillforts. In: M. O. Altan (ed.): Proceedings of the XIXth International Symposium CIPA 2003, New Perspectives To Save Cultural Herritage, Antalya (Turkey) 30 September - 04 October, 2003, CIPA Istambul, pp. 389-391.

Krrivánek, R., 2005. Geophysical survey in the archaeologically univestigated parts of Czech oppida. In: S. Piro (ed.): Proceedings, Extended Abstracts - 6th International Conference on Archaeological Prospection, Rome, Italy September 14-17, 2005, Institute of Technologies Applied to Cultural Heritage (C.N.R.), Roma, pp. 17-20.

Křivánek, R., 2006. Magnetometric prospection of various types of large ditched enclosures in Bohemia. Archaeological prospection vol. 13/1, Wiley InterScience, Gaffney, C. Aspinall, A. - Conyers, L. B. (eds.), pp. 25-43.

Křivánek, R., 2008. Geophysical survey in the archaeologically un-investigated parts of Czech oppida. In: Martin, L. (ed): ISAP News, Issue 14, January 2008, The newsletter of the International Society for Archaeological Prospection, Bradford, pp. 7-10, http://www.archprospection/isapnews/isapnews14.php.

Křivánek, R., 2010. Geofyzikální průzkum hradišt' Přerovská hůra a Zámka ohrožených stavebním záměrem - geophysical survey of the Přerovská Hůra and Zámka hillforts (Central Bohemia) threatened by future building activity. Archeologické rozhledy LXII/3, ARÚ Praha - Institute of Archaeology Prague, pp. 480-491.

Krrivánek, R., 2011. Contribution of geophysical surveys to changes of archaeological interpretation on examples of various enclosed sites in Bohemia. In: Drahor, M.; Berge, M (eds.): Archaeological prospection, Archaeology and art publications, 2011 Izmir, pp. 136-139.

Křivánek, R., 2013a. Geophysical surveys of abandoned quadrangular enclosures ("Viereckschanzen") from La Tène 
period in Bohemia. In: Fry, R. - Brown, H. (eds.): ISAP News, Issue 36, August 2013, The newsletter of the International Society for Archaeological Prospection, Bradford, pp. 5-7, http://www.archprospection.org/isapnews/isapnews-36.

Křivánek, R., 2013b. Changes of structure and extent od Early Medieval strongholds in Central Bohemia from geophysical surveys of sites. In: Neubauer, W. - Trinks, I. - Salisbury, R. B. - Einwögerer (eds.): Archaeological prospection. Proceedings of the 10th International Conference on Archaeological Prospection, Vienna, May 29th - June 2nd 2013. Austrian Academy of Sciences Press, Wien, pp. 281-284.

Křivánek, R., 2013c. Geofyzikální průzkum nově prokázaného pravěkého hradiště na k. ú. Zlončice, okr. Mělník. Archeologie ve středních Čechách, ročník 17/1, 2013. ÚAPPSČ, Praha, pp. 115-120.

Křivánek, R., 2014. Archeogeofyzikální průzkumy Archeologického ústavu AV ČR Praha v jižních Čechách v letech 2012-2013. Archeologické výzkumy v jižních Čechách 27, Č. Budějovice, pp. 371-382.

Křivánek, R., 2015. Chapter 27. Hillfort investigations in the Czech Republic. In: M. Carver - B. Gaydarska - S. M. Subías (eds): Field archaeology from around the world. Ideas and approaches. Springer Briefs in archaeology. Springer International Publishing Switzerland, pp. 157-161.

Křivánek, R. (ed.), Danielisová, A., Drda, P., 2013. Geofyzikálni průzkum oppid v Čechách. Zhodnoceni projektu (2003-2007). - Geophysical survey of oppida in Bohemia. The evaluation of project (2003-2007). Archeologické studijní materiály 23 , Prague.

Křivánek, R., Mařík, J., 2009. Early Medieval stronghold Libice nad Cidlinou. An example of use of geophysical methods in systematic non-destructive archaeological project. ArcheoSciences, revue d'archéométrie, suppl. 33 (Mémorie du sol, espace des hommes), Presses de Universitaires de Rennes, pp. 93-95.

Křivánek, R., Tabaka, A., 2011. Stratygrafia wybranych grodów centralnych najstarszego państwa Przemyślidów i państwa Piastów w świetle porównawczych badań nieinwazyjnych Ostrów Lednicki. In: Jasiewicz, J.; Lutyńska, M.; Rzeszewski, M.; Szmyt, M.; Makohonienko, M. (eds.): Metody geoinformacyjne $w$ badaniach archeologicznych. Poznań, pp. 52-56.

Kuna, M. et al., 2004. Nedestruktivni archeologie. Teorie, metody a cile - Non-destructive archaeology. Theory, methods and goals. Prague, Academia.

Linck, R., Fassbinder, J. W. E., Papathanassiou, K. 2011. Křivánek, R., 2011. Multipol-SAR-Survey of the UNESCO World Heritage Site Palmyra (Syria). In: Drahor, M.; Berge, M (eds.): Archaeological prospection, Archaeology and art publications, 2011 Izmir, pp. 21-24.

Löcker, K., Nau, E., Neubauer, W., Hinterleitner, A., 2009. Magnetic surveys of Early and Middle Neolithic settlements in Austria. ArcheoSciences, revue d'archéométrie, suppl. 33 (Mémorie du sol, espace des hommes), Presses de Universitaires de Rennes, pp. 101-104.

Mařík, J., Křivánek, R., 2012. Nedestruktivní výzkum akropole libického hradiště - Non-destructive research on the inner bailey of the Libice nad Cidlinou stronghold. Sborník Národního muzea $v$ Praze = Acta Musei nationalis Pragae. Řada A, Historie-Series A, Historia. Roč. 66, 1-2, pp. 67-70.

Querrien, A., Moulin, J., Tabbagh, A., 2009. Confrontation of geophysical survey, soil studies and excavation data to evidence tillage erosion. ArcheoSciences, revue d'archéométrie, suppl. 33 (Mémorie du sol, espace des hommes), Presses de Universitaires de Rennes, pp. 195-198.

Sirri Seren, S., Löcker, K., Hinterleitner, A., Neubauer, W., Ladstätter, S., 2011. Ephesos revisited. A decade of geophysical prospection of different field conditions in Ephesos, Turkey. In: Drahor, M.; Berge, M (eds.): Archaeological prospection, Archaeology and art publications, 2011 Izmir, pp. 90-92. 